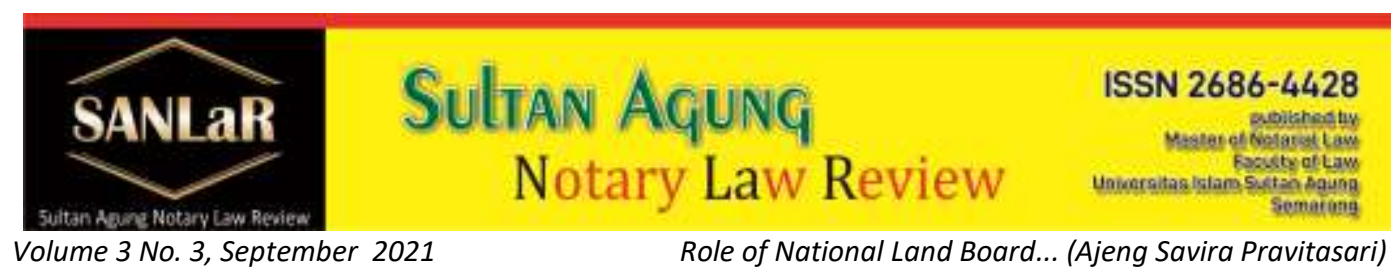

\title{
Role of National Land Board Office in Implementation of Prohibition of Absentee Land Ownership
}

\author{
Ajeng Savira Pravitasari*) \\ ${ }^{*}$ Faculty of Law, Universitas Islam Sultan Agung (UNISSULA) Semarang, E-mail: \\ ajengsp2021@gmail.com
}

\begin{abstract}
The research objectives are: 1) To find out and analyze the factors that cause absentee land ownership in Kendal Regency. 2) Knowing abou

$t$ the role of the Kendal Regency Land Agency in dealing with and solving land problemsabsentee. The data used in this study are primary data, secondary data, and tertiary data that can support the assessment, which is then analyzed using empirical juridical methods. Based on the results of data analysis, it is concluded that: 1) in Article 3 paragraph (1) of Government Regulation Number 224 of 1961 jo. Government Regulation Number 41 of 1964 (State Gazette of the Republic of Indonesia of 1961 Number 280, Supplement to the State Gazette Number 2322 hereinafter referred to as PP Number 224 of 1961, states that: Agricultural land owners who reside outside the sub-district where the land is located, within a period of 6 (six) months are required to transfer their land rights to another person in the sub-district where the land is located or move to the sub-district where the land is located. The main factors that cause absentee land ownership are from the community that the community lacks legal awareness, and only wants to seek economic benefits derived from absentee land ownership. Cultural factors such as inheritance and infrastructure. In the facilities and infrastructure there are no reports that are helpful in overcoming absentee land ownership from Village and District officials, as well as a lack of coordination and cooperation. 2) in overcoming absentee land problems, the National Land Agency has a role and contribution to reduce absentee land ownership in Kendal Regency, namely by carrying out legal enforcement by conducting legal counseling that is directed and carried out continuously widely to the community. This counseling can be done by coming to the field to collect or monitor the state of the inventory to the regions, namely monitoring the sub-districts, where the sub-district is a center rather than a transfer of rights so that there is no absentee land sale and purchase.
\end{abstract}

Keywords: Factors; Agency; Absentee; Land; Notary. 


\section{Introduction}

Soil is a specific unit area of the earth's surface. In customary law, land is a soulful object that cannot be separated from its fellowship with living creatures such as humans. Because land is one of the most important resources for society, both as a space or a place to carry out various activities and as a medium for growing plants owned by humans. Land has various meanings, both philosophical, sociological and economic meanings. In a broad sense, land includes all elements, namely earth, water, air, as well as natural resources and the relationship between them as the center, as well as spirits in the supernatural realm that are interwoven as a whole.

Land is one of the national wealth resources, unifying the region, the gift of God Almighty, and is proof of the prosperity of the people. Prosperity can be obtained through efforts to provide added value or useful results in order to improve welfare in society. Besides that, land is also one of the factors of production which is very vital for human life and the development of a nation. Land in the development period increases in importance, because of an increase in the volume of development in agriculture, environmental sustainability, safeguarding natural resources and so on.

For farmers, land is the most important resource for survival, because agricultural land is needed by farmers to increase agricultural yields and one of the efforts to survive. Because of the importance of the value of land in a nation, agricultural land is used as a support for food security in an agrarian country. Because of the importance of land, agricultural land needs to be regulated so that it is not controlled on a large scale by only a few parties.

It is stated in Article 33 paragraph (3) of the 1945 Constitution of the Republic of Indonesia, hereinafter referred to as the 1945 Constitution of the Republic of Indonesia, which states that: "Earth and water and the natural resources contained therein are controlled by the state and used for the greatest prosperity of the people." This article contains the meaning of granting power to the state to fully regulate natural resources within the territory of the Unitary State of the Republic of Indonesia in the context of the welfare of all Indonesian people.

The result of the realization of Article 33 paragraph (3) of the 1945 Constitution of the Republic of Indonesia is the issuance of Act No. 5 of 1960 concerning Basic Agrarian Regulations (State Gazette Number 104 of 1960, Supplement to State Gazette Number 2043) hereinafter referred to as UUPA, which regulates concerning land law in accordance with the spirit of the Indonesian nation, which came into force on September 24, 1960. 
The objectives of the promulgation of the UUPA are to:

a. Laying the foundations for the preparation of the National Agrarian Law as a tool to bring prosperity, happiness and justice to the state and people, especially the peasants, in the context of realizing a just and prosperous society;

b. Laying the foundations for unity and simplicity in land law;

c. Laying the foundations to provide legal certainty regarding land rights for all people.

From the embodiment of the Law, the issuance of statutory regulations, one of which is Act No. 56 Prp of 1960 concerning Determination of Agricultural Land Area (State Gazette of the Republic of Indonesia of 1960 Number 174, Supplement to the State Gazette of the Republic of Indonesia Number 5117), hereinafter referred to as The Land Reform Law, which aims to increase the income and standard of living of land-cultivating farmers, is a foundation or prerequisite for carrying out economic development towards a just and prosperous society based on Pancasila.

Agricultural land and land reform have a very close relationship. Because land reform is an arrangement regarding ownership of agricultural land with humans. In order to realize the objectives of the LoGA and land reform, the law governing land reform describes the programs of land reform.

The programs include:

a. Limitation of the maximum area of land tenure;

b. Prohibition of absentee land ownership;

c. Redistribution of lands that are in excess of the maximum limit, lands subject to absentee prohibitions, ex-self-government lands and state lands;

d. Arrangements for the return and redemption of pawned agricultural lands;

e. Re-arrangement of the agreement for agricultural land.

The determination of the minimum area of ownership of agricultural land is accompanied by a prohibition on carrying out actions that result in the division of ownership of agricultural land into parts that are too small.

The reciprocity of land reform and agriculture clearly has a big influence on it, because there is a goal of increasing productivity. If you have a land area that exceeds the limit for the cultivation process, it will give a low percentage as well, especially if the owner is absentee landlors, who do not carry out cultivating 
activities on their own land, but the care and management is left to the people who live in that area ${ }^{1}$.

The legal basis for the prohibition on absentee land ownership is Article 10 paragraph (1) of the UUPA, that is, every person and legal entity that has a right to agricultural land is in principle required to work or actively cultivate it themselves, by preventing extortion².

Prohibition of Agricultural Land Ownership in absentee is the owner of agricultural land which is located outside the area where the owner lives. Where property rights to land are the strongest basis for rights granted by the State to the community that can be used in various aspects of life. However, Article 10 of the LoGA expressly prohibits absentee ownership of land, as stated as follows ${ }^{3}$ :

1) Every person or legal entity that has a right to agricultural land is in principle obliged to work or actively cultivate it by himself, by preventing extortion;

2) The implementation of the provisions of paragraph (1) will be further regulated by laws and regulations;

3) Exceptions to the principle in paragraph (1) are regulated in laws and regulations.

Based on the provisions stated above, the LoGA provides guarantees in the form of legal certainty to every citizen, without distinguishing between rich and poor citizens to have rights to the agricultural land. The LoGA also provides legal protection in the form of extortion by rich land owners against poor people, such as farmers, cultivators, or farm laborers in their work only unfair profit sharing agreements that are more profitable for the land owner, by requiring the land owner to work or cultivate the land himself.

It has been more than half a century since the BAL, which limits land ownership, has not changed to what is expected. This is evident from absentee land ownership, which appears to be known, but is difficult to prove due to various reasons.

\footnotetext{
${ }^{1}$ A Chuasanga, Ong Argo Victoria. (2019). Legal Principles Under Criminal Law in Indonesia Dan Thailand, Jurnal Daulat Hukum, Vol 2, $\quad$ No 1 (2019) http://jurnal.unissula.ac.id/index.php/RH/article/view/4218 see Alam, Bahrul., \& Khisni, Akhmad. (2020). Legal Protection of Holders of Land Loss Data In The City Land Office of Kendari. JURNAL AKTA: Vol.7, No. 2, 159-164. Retrieved from http://jurnal.unissula.ac.id/index.php/akta/article/view/7963

${ }^{2}$ Arrohim, Mohammad B., \& Wahyuningsih, Sri Endah. (2020). Analysis of Judicial Application of Criminal Penalty Against Notary / Land Deed Officials Conducting Making Crime of the Fake Authentic Deed in State Court of Semarang. JURNAL AKTA: Vol.7, No. 2, 183-188. Retrieved from http://jurnal.unissula.ac.id/index.php/akta/article/view/7891

${ }^{3}$ Deen, Thaufiq., Ong Argo Victoria \& Sumain. (2018). Public Notary Services In Malaysia. JURNAL AKTA: Vol. 5, No. 4, 1017-1026. Retrieved from http://jurnal.unissula.ac.id/index.php/akta/article/view/4135
} 
As we already know, that in Article 3 paragraph (1) Government Regulation Number 224 of 1961 jo. Government Regulation Number 41 of 1964 (State Gazette of the Republic of Indonesia of 1961 Number 280, Supplement to the State Gazette Number 2322 hereinafter referred to as PP Number 224 of 1961, states that: "Agricultural land owners who reside outside the sub-district where the land is located, within six (6) months are obligated to transfer their land rights to another person in the sub-district where the land is located or move to the sub-district where the land is located". In Article 3 of PP No. 224 of 1961, it stipulates that those who are exempted from owning land in absentee, among others ${ }^{4}$ :

a. For landowners residing in a sub-district bordering the sub-district where the land is located, provided that the distance between the owner's residence and the land is still possible to work on the land efficiently according to the consideration of the level II regional land reform committee;

b. Those who are carrying out state duties, fulfilling religious obligations or having other special reasons that can be accepted by the Minister of Agrarian Affairs;

c. For civil servants and military officials as well as those who are equated with those who are carrying out state duties.

If a lie is found in land ownership or it is not in accordance with the obligations as above, sanctions will be given and absentee land owned by the owner of the excess land, the land owned must be given to the government and then used in the landeform land function. Compensation will be given to the former owner in accordance with applicable regulations. In practice, there is a lot of agricultural land located in agricultural areas that should be owned by the indigenous people of the area but have changed ownership rights by residents outside the land ownership area.

In connection with this, the land owner needs to settle in the sub-district where the land is located, so that he can do everything according to the principles contained in Article 10 of the UUPA as for what is stipulated, among others:

1) Every person and legal entity that has a right to agricultural land is in principle obliged to work or actively cultivate it by himself, by preventing extortion;

2) The implementation of the provisions of paragraph (1) will be further regulated by law;

3) Exceptions to the principle in paragraph (1) are regulated in laws and regulations.

Even though this prohibition is still in effect, in reality absentee land ownership is often found in Kendal Regency. Moreover, Kendal Regency is one of the districts

\footnotetext{
${ }^{4}$ Deen, Thaufiq., Ong Argo Victoria \& Sumain. (2018). Public Notary Services In Malaysia. JURNAL AKTA: Vol. 5, No. 4, 1017-1026. Retrieved from http://jurnal.unissula.ac.id/index.php/akta/article/view/4135
} 
that can be said to be a fertile agricultural area, especially its rice fields. In such regional conditions, residents of Kendal Regency generally make a living as farmers, either as laborers or owners of agricultural land.

In fact, whether or not this regulation applies, absentee agricultural land owners or absentee land rulers are widely found in areas or agricultural areas in each region. Because in every area there are communities that rely on agriculture as a livelihood 5 .

This is also due to a change in thinking that agricultural land can be used in other ways, such as being an investment for industry or housing, or land for business development. Because of the change in mindset, the community is concerned with linking agricultural land to meet their daily needs.

With the increase in population growth and the demand for residential land, it causes a decrease or reduction in agricultural land, not least in the Kendal Regency area. Agricultural land is still used as an object of speculation which causes the area of agricultural land to decrease due to a shift in function.

Absentee land ownership can be obtained through buying and selling, inheritance, and so on as well as processing that is not carried out properly but is only used for investment facilities and then later can be resold after an increase in price. So that juridically the problem that arises is the effectiveness of the laws and regulations governing the land reform program, one of which is the prohibition of absentee land ownership.

It can be said that land reform is a failed attempt, because in land reform the prohibition of absentee ownership of land based on the maximum limit of agricultural land cannot be implemented properly. In this regard, the role of law enforcement in this case is the National Land Agency as the implementer of policies in the land sector, which is expected to be able to provide socialization of existing regulations regarding the prohibition of absentee land ownership to all residents or the community in order to support the implementation of the land reform program itself ${ }^{6}$.

Based on the background stated above, the authors are interested in conducting further research which will be outlined in the form of research with the title The Role of the National Land Agency Office in the Implementation of Article 10 of the Basic Agrarian Law concerning the Prohibition of Ownership of Absentee Land Rights in Kendal Regency.

\section{Research Methods}

\footnotetext{
${ }^{5}$ Ong Argo Victoria, (2018) Waqf Al-Nuqūd In Indonesia (In Law Perspective), Jurnal Pembaharuan Hukum Vol 5, No 1 Universitas Sultan Agung, http://jurnal.unissula.ac.id/index.php/PH/article/view/2999

${ }^{6}$ Sukarmi, S., \& Victoria, A. (2018). Cash Waqf in Sustaining Of Indonesian Society "In Legal \&amp; Economic Perspective". AL-ITQAN: JOURNAL OF ISLAMIC SCIENCES AND COMPARATIVE STUDIES, 2(1), 83-97. https://doi.org/10.31436/al-itqan.v2i1.43
} 
The approach method used in this legal research is a sociological juridical approach. The research specification is a descriptive analytical approach, describing the state of the object under study as it is based on the actual facts that exist at this time. The data collection method uses library research and observation methods.

\section{Results and Discussion}

\subsection{Factors Encouraging Absentee Land Ownership}

The problem of ownership of agricultural land in its relationship between the landlord and the farmers who cultivate it is one of the most actual problems in agriculture, especially in developing countries including Indonesia.

Currently the issue of ownership of agricultural land is the subject of discussion, this is due to the influence of the development of the land tenure and ownership system in the Dutch East Indies era, where the understanding of capitalism and feudalism as well as the liberal concept of individualism inherited by colonial law still influences the behavior of landowners in ownership and possession of the land.

In fact, farmers who own land are sometimes in urgent need of money which is expected from the proceeds of the sale of their land. The owners of money who buy agricultural land in villages are generally urban people who already have jobs not as farmers, and they live and settle in cities. This is one of the reasons for the emergence of absentee ownership of agricultural land.

Ownership of agricultural land in absentee itself is expressly prohibited by the LoGA. This prohibition relates to the main provisions in the Landreform which are regulated in Article 7, Article 10 and Article 17 of the LoGA. Article 7 of the UUPA reads: "In order not to harm the public interest, ownership and control of land that exceeds the limit is not allowed".

This is an effort to prevent the existence of individual rights that exceed the limit. Article 10 of the UUPA reads: Every person and legal entity that has a right to agricultural land is required to work or cultivate it themselves actively by preventing extortion. The provisions in Article 10 have the purpose of preventing the formation of landlords, who live in big cities, who are just waiting for the results of the lands that are cultivated and cultivated by people who are under their orders and powers.

The provisions in Article 17, regarding the maximum limits for the extent of this land can be seen as a continuation of what is stated in Article 7. With the provisions of this maximum limit, the accumulation of land in certain groups can be avoided.

As the implementation of Article 7 and Article 17 of the LoGA, Act No. 56 Prp of 1960 concerning Determination of Agricultural Land Area has been promulgated. 
To carry out land redistribution as mandated by Article 17 (3) of the LoGA in conjunction with Act No. 56 Prp of 1960, PP No. 224 of 1961 has been enacted which was later amended by PP. 41 of 1964.

The prohibition of absentee land on agricultural land is regulated in PP. 224 of 1961 on Article 3 and PP No. 41 of 1964 on additional articles, namely Articles 3a to $3 e$. However, it turns out that these provisions still need to be refined, namely with PP No. 41 of 1964 which provides stricter provisions ${ }^{7}$.

So based on the results of the author's research in the field, it can be seen that the factors that cause absentee agricultural land in Kendal Regency:

a. Community factors, namely the lack of legal awareness of the community. Community life can run in an orderly and orderly manner, of course, it is supported by the existence of an order so that life becomes orderly. In society, order is certainly something that is very necessary, especially to create peace in the association of human life, that peace means that there is order (outwardly) and tranquility (inward). that is :
a. Legal knowledge;
b. Legal understanding;
c. Legal attitude;
d. Legal behavior.

In this case, although the government has tried to prevent absentee ownership of agricultural land, this cannot be separated from the participation of the community to comply with existing regulations. This is inseparable from the intention of someone who already knows about the regulations regarding the prohibition of absentee ownership of agricultural land, they deliberately violate these regulations for their own economic benefit.

Absentee agricultural land that occurs due to buying and selling under the hands, is generally produced by the owner by the local population as sharecroppers. This kind of legal relationship is generally accepted and for the local population, especially the sharecroppers, it is considered quite beneficial in terms of both economic and social/family relations.

\section{b. Cultural Factor}

In relation to the factors that cause absentee land from the cultural aspect, namely because of inheritance. This inheritance is a form of patterned behavior from humans themselves. Inheritance is actually a legal event that is commonplace in every family, but this legal event is important to note in connection with the prohibition of absentee ownership of agricultural land,

${ }^{7}$ Victoria, O. A., \& ., M. (2021). Doctor's Constributions in Transportation Monitoring During COVID-19 Pandemic. KnE Social Sciences, 5(1), 598-618. https://doi.org/10.18502/kss.v5i1.8317 
especially if the heirs are far outside the sub-district where the agricultural land is located. The absentee ownership of agricultural land can actually be avoided if the heirs move to the sub-district where the inherited land is located, or the inherited land is transferred to residents who live in that sub-district.

However, in reality what is found in the field, that inheritance is rarely followed by the distribution of inheritance within a period of one year from the death of the heir.

In addition, according to the view of the farming family, selling inherited land should only be done in a forced situation, for example if there is a family that requires hospitalization costs.

Therefore, the juridical alternative offered in order to avoid the absentee land provisions is difficult to fulfill. However, even if this happens, village heads or village officials generally protect the interests of the heirs. The considerations that are used as the basis for doing so are partly because they know both the heir and his heirs. The heirs generally stated that they wanted to keep the inheritance land as a support for life in old age. The desire to migrate for them is to improve their lives, and when they are old they want to spend the rest of their lives in their hometown. For this reason, village officials have never reported the occurrence of absentee land due to the inheritance. Even if there is inheritance, the heirs who are overseas are always considered to be residents of the village. Thus, absentee lands which materially do exist and occur because of inheritance, the data has never been formally known, thus escaping the possibility of being determined by the government as objects of land reform.

Thus, judging from the values that live in farming communities, the prohibition of absentee land ownership because inheritance is not in accordance with their wishes. The farmers almost all said the concept of agricultural land for farmers and must be cultivated themselves must be enforced. Many agricultural lands are neglected or not properly cultivated because the owners are not farming families and live in other areas, generally in urban areas and have other sources of livelihood.

c. Legal Factor

It has been known previously that the provisions on the prohibition of absentee land ownership include coercive legal provisions, in other words, the provisions in Article 10 of the LoGA include regulations that cannot be overridden.

From a legal perspective, it is clear that formally all of the regulations governing the law are valid, because they were formed by authorized officials/agencies and in their formation have gone through the process as determined.

However, from a material point of view, all regulations governing the prohibition of absentee ownership/control of agricultural land are products of the 1960s.

d. Factors of the Apparatus or Law Enforcement

Regarding absentee land issues and problems, in fact the existence of the Camat/Village Head is very strategic in assisting the implementation of the provisions on absentee land issues. However, these strategic roles cannot work 
properly and sometimes even clash with each other. For example, village and sub-district officials are considered to be the cause of the occurrence of dual ID cards, causing the transfer of agricultural land to other parties who do not physically reside in the same sub-district but materially the sale and purchase of the land has been legal.

e. Economic Factor

As it is known that land has a very important value because it has economic value. For a farmer, agricultural land is a source of life, a symbol of status in an agrarian society. Therefore, it is impossible for a farmer to leave his farm, letting his land become absentee land. Thus, the ignorance of a farmer regarding the prohibition of absentee land ownership does not have the potential to give birth to absentee land. The trend that appears in farming communities is land ownership that exceeds the maximum limit. This tendency occurs because of the cultural values of the farming community itself.

3.2. The Role of the National Land Agency Office in Absentee Land Ownership The Land Office is a vertical agency of the National Land Agency (BPN) in each Regency/City area, led by a Head, who is directly responsible to the Head of the Provincial BPN Regional Office. This office has 3 main tasks as follows:

a. Prepare and carry out activities in the field of land tenure regulation, redistribution, joint use of land, and urban and rural land consolidation;

b. Prepare and carry out data collection activities for controlling land tenure, payment of compensation for maximum excess land, absentee, and private land, granting transfer permits and problem solving;

c. Carry out business and household affairs.

The three main tasks are operationally distributed to four work units at the Land Office, namely ${ }^{8}$ :

\section{Land Use Section (PGT)}

This work unit has the following main tasks:

a. Collect, process and present land use data

b. Prepare the preparation of land use plans, provide guidance on land use to the community and prepare for controlling changes in land use.

\section{Section of Land Rights (HAT)}

The HAT work unit has the following main tasks:

a. Prepare and carry out inspection activities and issue fatwas regarding the granting, renewal, extension of time period, termination, and cancellation of land rights;

b. Prepare and carry out activities in the field of land acquisition for Government agencies;

c. Prepare and carry out settlement of land problems.

Land Measurement and Registration Section (P2T)

This work unit has the following main tasks:

8 Ibid. 
a. Identifying, measuring, mapping and preparing land registration for land conversion belonging to indigenous peoples;

b. Prepare registration of land rights based on the granting of rights and recognition of rights, collect data and information for the preparation of information systems for the preparation of land information systems and maintain general registers and certificates in the field of land measurement and registration.

c. Prepare settlement of transfer of land rights, imposition of land rights and materials for guidance/guidance of Land Deed Maker Officials (PPAT) as well as preparing means/materials for listing entries in the field of land measurement and registration.

\section{Land Use Section (PGT)}

This work unit has the following main tasks:

a. Collect, process and present land use data;

b. Prepare the preparation of land use plans, provide guidance on land use to the community and prepare for controlling changes in land use.

\section{Closing}

The prohibition on absentee land ownership has not been implemented and implemented effectively, because it is caused by several factors, namely: The lack of legal awareness of the community, namely there is still a lot of buying and selling of land that is carried out under the hands and the transfer is not registered at the Land Office. Cultural factor is inheritance. Factors of facilities and infrastructure, and the role of the Land Office in overcoming absentee land ownership is administrative control, namely by carrying out strict supervision of the transfer of rights to agricultural land through cooperation between the relevant agencies, namely the Village Head, District and PPAT/Notary. Law enforcement, namely through legal counseling that is directed and carried out continuously widely to the community as well as officials / officials related to land issues.

\section{References}

Journals:

[1] Syahyuti. 2006, Nilai-nilai Kearifan pada Konsep Penguasaan Tanah Menuruut Hukum Adat di Indonesia, Jurnal Forum Penelitian Agro Ekonomi, Vol 24.

[2] A Chuasanga, Ong Argo Victoria. (2019). Legal Principles Under Criminal Law in Indonesia Dan Thailand, Jurnal Daulat Hukum, Vol 2, No 1 http://jurnal.unissula.ac.id/index.php/RH/article/view/4218

[3] Alam, Bahrul., \& Khisni, Akhmad. (2020). Legal Protection of Holders of Land Loss Data In The City Land Office of Kendari. JURNAL AKTA: Vol.7, 
No. 2, 159-164. Retrieved from http://jurnal.unissula.ac.id/index.php/akta/article/view/7963

[4] Arrohim, Mohammad B., \& Wahyuningsih, Sri Endah. (2020). Analysis of Judicial Application of Criminal Penalty Against Notary / Land Deed Officials Conducting Making Crime of the Fake Authentic Deed in State Court of Semarang. JURNAL AKTA: Vol.7, No. 2, 183-188. Retrieved from http://jurnal.unissula.ac.id/index.php/akta/article/view/7891

[5] Deen, Thaufiq., Ong Argo Victoria \& Sumain. (2018). Public Notary Services In Malaysia. JURNAL AKTA: Vol. 5, No. 4, 1017-1026. Retrieved from http://jurnal.unissula.ac.id/index.php/akta/article/view/4135

[6] Ong Argo Victoria, (2018) Waqf Al-Nuqūd In Indonesia (In Law Perspective), Jurnal Pembaharuan Hukum Vol 5, No 1 Universitas Sultan http://jurnal.unissula.ac.id/index.php/PH/article/view/2999

[7] Sukarmi, S., \& Victoria, A. (2018). Cash Waqf in Sustaining Of Indonesian Society "In Legal \&amp; Economic Perspective". AL-ITQAN: JOURNAL OF ISLAMIC SCIENCES AND COMPARATIVE STUDIES, 2(1), 8397. https://doi.org/10.31436/al-itqan.v2i1.43

[8] Victoria, O. A., \& ., M. (2021). Doctor's Constributions in Transportation Monitoring During COVID-19 Pandemic. KnE Social Sciences, 5(1), 598-618. https://doi.org/10.18502/kss.v5i1.8317

Books:

[1] Ali Achmad Chomzah. 2004. Hukum Agraria (Pertanahan) Indonesia, Jilid I, Prestasi Pustakaraya, Jakarta.

[2] Effendi Perangin, 1986, Hukum Agraria di Indonesia Suatu Telaah Dari Sudut Pandang Praktisi Hukum, Rajawali, Jakarta.

[3] John M. Echlos dan Hasan Sadily. 1996. Kamus Inggris-Indonesia, Gramedia, Jakarta.

[4] K. Wantjik Saleh, 1985, Hak Anda Atas Tanah, Ghalia Indonesia, Bandung.

[5] Supriadi, 2007, Hukum Agraria, Sinar Grafika, Jakarta.

Internet:

https://mirdinatajaka.blogspot.com/2017/05/teori-keadilan-hukum.html 